\title{
Dried Fruit Matrices Incorporated with a Probiotic Strain of Lactobacillus plantarum
}

\author{
Catarina Ribeiro ${ }^{a}$, Ricardo Freixo ${ }^{a}$, Johna Silva ${ }^{a}$, Paul Gibbs $^{a}$, Alcina M. M. B. \\ MORAIS $^{\mathrm{a}}$, AND PAUla TEIXEIRA ${ }^{\mathrm{a}^{*}}$ \\ ${ }^{a}$ CBQF - Centro de Biotecnologia e Química Fina - Laboratório Associado, Escola Superior de Biotecnologia, \\ Universidade Católica Portuguesa/Porto, Rua Dr. António Bernardino Almeida, 4200-072 Porto, Portugal \\ ${ }^{*}$ Corresponding author \\ pcteixeira@porto.ucp.pt
}

Received: 1 August 2013; Published online: 18 April 2014

\begin{abstract}
The development of fruits and vegetables containing probiotics is a topic of great interest and popularity for health-conscious consumers. The aim of this study was to evaluate the possibility of using dried fruit matrices as delivery vehicles for probiotics. Different fruits - kiwi, mango, strawberry, pineapple, banana - were used as food matrices to test the viability of a strain of Lactobacillus plantarum, which was determined after drying at $40^{\circ} \mathrm{C}$ and at different storage times. Cell survival after drying decreased by ca. $1 \log$ in banana and strawberry, to $3 \log$, for kiwi. The bacterial numbers in banana and strawberry dried pieces at the time of storage at room temperature and $4^{\circ} \mathrm{C}$ were approximately $10^{7} \mathrm{cfu} / \mathrm{g}$. After 37 days storage at room temperature, no viable counts were observed in any of the fruits studied. However after this period of time at $4^{\circ} \mathrm{C}$, viable cells were detected for all the fruits $\left(1.9 \times 10^{6} \mathrm{cfu} / \mathrm{g}, 1.5 \times 10^{5} \mathrm{cfu} / \mathrm{g}, 1.5 \times 10^{5} \mathrm{cfu} / \mathrm{g}, 4.7 \times 10^{4} \mathrm{cfu} / \mathrm{g}, 8.0 \times 10^{3} \mathrm{cfu} / \mathrm{g}\right.$, for strawberry, banana, kiwi, mango and pineapple, respectively).
\end{abstract}

Keywords: Healthy dried fruit; Probiotic; Lactobacillus plantarum; Viability

\section{Introduction}

Fruits and vegetables are essential components of the human diet. Apart from being good sources of vitamins, minerals, and fibre, these foods are also a rich source of potentially bioactive compounds (Palafox-Carlos, Ayala-Zavala, \& Gonzalez-Aguilar, 2011). Additionally, the consumption of fresh fruits and also functional foods e.g. probiotics, has increased considerably in recent years, due to the increasing concern of consumers about food and the effects on health. Combinations of fruits or vegetables with probiotics (Fito et al., 2001; Alegre, Vinas, Usall, Anguera, \& Abadias, 2011), would create a better, more convenient, products for consumers.

The incorporation of probiotic strains in sev- eral food matrices has been studied, mainly with respect to their therapeutic benefits (LourensHattingh \& Viljoen, 2001). This represents a challenge, since the viability of the incorporated cells in the food matrix depends on several factors, such as $\mathrm{pH}$, storage temperature, oxygen levels, and presence of competing microorganisms and inhibitors (Mattila-Sandholm et al. 2002).

Probiotics can be added either to fresh foods with high water activity $\left(\mathrm{a}_{w}\right)$ as well as to low $\mathrm{a}_{w}$ dry foods. Fresh foods normally have a shelf-life of a few weeks, e.g. yogurts, while the shelf-life of dried products is increased to months, as in the case of milk powder (Weinbreck, Bodnar, \& Marco, 2010).

Following results already obtained with apple 
(Rêgo et al., 2013), the principal objective of this research was to evaluate the possibility of using other dried fruit matrices - kiwi, mango, strawberry, pineapple, banana — as delivery vehicles for probiotics.

The specific objective of the present work was to evaluate the survival of a probiotic strain of $\mathrm{Lac}$ tobacillus plantarum incorporated into the fruit matrices during drying and subsequent storage.

\section{Materials and Methods}

\subsection{Probiotic bacteria and growth conditions}

Lactobacillus plantarum, previously isolated from kefir and described as a probiotic strain (Golowczyc, Mobili, Garrote, Abraham, \& De Antoni, 2007, 2010) was selected for the present study from the culture collection of Escola Superior de Biotecnologia, Universidade Católica Portuguesa (ESB- strain code MGLp). The strain was stored in MRS broth (Pronadisa, Madrid, Spain) plus glycerol $(30 \% \mathrm{v} / \mathrm{v})$ at $-80^{\circ} \mathrm{C}$, until use. After resuscitation of the stock culture on MRS agar plates (Pronadisa; $24 \mathrm{~h}$ at $37^{\circ} \mathrm{C}$ ), the pre-inoculum was prepared in MRS broth (15 $\mathrm{mL}$ ), inoculated with a single colony of the selected strain, incubated at $37^{\circ} \mathrm{C}$ for 24 hours. The pre-inoculum $(5 \mathrm{~mL}, 1 \% \mathrm{v} / \mathrm{v})$ was added to $500 \mathrm{~mL}$ of MRS broth and further incubated at $37^{\circ} \mathrm{C}$ for 24 hours. This culture was centrifuged in sterile $50 \mathrm{~mL}$ Falcon tubes, $\left(5000 \mathrm{x}\right.$ g at $4^{\circ} \mathrm{C}$; Hettich Zentrifugen Rotina 35R, Germany) for 5 minutes followed by two washes of the pelleted cells by re-suspension and centrifugation, with sterile Ringer's solution (Merck, Germany, Darmstadt), under the same conditions. Cell pellets were then re-suspended in $20 \mathrm{~mL}$ of Ringer's solution in each Falcon tube in order to concentrate the probiotic suspension before adding to the fruit matrices.

\subsection{Sample preparation}

The fruits used in this study were kiwi, variety 'Hayward', mango, variety 'Tommy', strawberry, variety 'Camarosa', pineapple, variety 'Gold' and banana, variety 'Cavendish'. All were obtained from local markets from the region of Porto. These varieties were chosen because they are commonly available. The fruits were washed with water, peeled and cut into slices of $0.75 \mathrm{~cm}$ thickness (banana, pineapple) and $1 \mathrm{~cm}$ (kiwi), cubes of $1.5 \mathrm{~cm}$ side (mango), using a mould to obtain pieces with regular dimensions, and halves (strawberry). These fresh cut fruits were immediately immersed in sterile Ringer's solution to inhibit the oxidation of the matrix (500 $\mathrm{g}$ of each fresh-cut fruit to 1L of sterile Ringer's solution), until submersion in the concentrated cell suspension prepared as described above. The pieces of fruits immersed in Ringer's solution were recovered by filtration using sterile gauze.

\subsection{Adherence of probiotic cells}

Each sample of fresh cut fruit was immersed in the probiotic suspension for one hour at room temperature. In order to make the adherence uniform in all pieces of fruits, gentle agitation was applied during immersion, ensuring that all were immersed in the cell suspension under the same conditions. Afterwards, the pieces were recovered by filtration under aseptic conditions using sterile gauze, placed on trays and then into the dryer (UOP8, Armfield, United Kingdom).

\subsection{Drying conditions}

A pilot-scale tray dryer (which promotes the drying of wet solid products by flowing hot air over the trays) was used. Drying was performed at about $40^{\circ} \mathrm{C}$ with an average speed of air circulation of $1.5 \mathrm{~m} / \mathrm{s}$. Drying of fresh-cut fruits with adhered LAB (by immersion at normal atmospheric pressure), occurred in 24 hours. Samples were taken at intervals during the drying process and survivors were enumerated. The water activity, $\left(\mathrm{a}_{w}\right)$, of the fruit pieces was also measured using a Hygroplam AW1 (Rotronic Instrument Corporation, USA).

\subsection{Storage conditions}

The dried fruit pieces were stored in sterile Schott flasks (flasks full with almost no head space) under normal atmospheric conditions. 
The samples were divided in order to determine if storage temperature had any effect on cell viability. Two storage temperatures were tested: room temperature $\left(\right.$ ca. $20^{\circ} \mathrm{C}$ ) and $4^{\circ} \mathrm{C}$. The $\mathrm{a}_{w}$ of the dried fruit pieces was also measured during storage.

\subsection{Bacterial enumeration}

One gram of fresh-cut fruits (freshly inoculated) were added to $9 \mathrm{~mL}$ of sterile Ringer's solution and mixed in a stomacher (BagMixer ${ }^{\circledR} 400 \mathrm{P}$, Interscience, France) for one minute. Then, serial decimal dilutions were made (Ringer's) and LAB enumerated by the drop count technique on MRS agar plates. Colony counting was performed after incubation at $37^{\circ} \mathrm{C}$ for 24 hours. The same procedure was followed for samples after drying but the sample weight was $5 \mathrm{~g}$ added to $45 \mathrm{~mL}$ of sterile Ringer's solution. The change in the water content of the sample after drying was taken into consideration when log cfu/g (of dried sample) values were calculated.

\section{Results and discussion}

The main objective of the present research was to evaluate the possibility of using dried fruit matrices - kiwi, mango, strawberry, pineapple, banana - as delivery vehicles for viable probiotic cells (at least $1 \times 10^{7} \mathrm{cfu} / \mathrm{g}$ ). A concentrated suspension of L. plantarum (ca. $10^{9} \mathrm{cfu} / \mathrm{mL}$ ) was produced to allow a high incorporation of the cells into the food matrix by immersion. From previous work (Rêgo et al., 2013), it was established that one hour of contact would be sufficient to promote good adherence with a high concentration of viable cells (ca. $10^{8} \mathrm{cfu} / \mathrm{g}$ ).

After one hour of immersion, a difference of one $\log$ was observed between numbers in the initial probiotic suspension (ca. $10^{9} \mathrm{cfu} / \mathrm{mL}$ ) and in the immersed fruit matrix $\left(10^{8} \mathrm{cfu} / \mathrm{g}\right)$, for all the fruits studied. Immersion was performed in normal atmosphere because, in a previous study with apple (Rêgo et al., 2013), no differences in viable counts were observed between immersion under normal atmospheric conditions and immersion under vacuum.

Fresh-cut kiwi, mango, strawberry, pineapple and banana with adhered probiotic bacteria were dried until a water activity of between 0.5 and 0.6 (data not shown). After drying, all fruits presented lower numbers of viable cells. This was especially notable in kiwi, which initially presented $2.3 \times 10^{8} \mathrm{cfu} / \mathrm{g}$ and suffered a $3 \mathrm{log}$ reduction. Pineapple and mango, that initially had $1.4 \times 10^{8}$ $\mathrm{cfu} / \mathrm{g}$ and $2.1 \times 10^{8} \mathrm{cfu} / \mathrm{g}$, respectively, suffered a decrease of about $2 \log$ in the number of viable cells. In banana, and strawberry the viability of $L$. plantarum immediately after drying was higher (ca. $10^{7} \mathrm{cfu} / \mathrm{g}$; a $1 \log$ reduction). The different results obtained for the different fruits may be related with both physical and chemical characteristics of the fruits. For example, banana has the lowest acidity ( $\mathrm{pH} 4.5-5.2)$ of these fruits, although the porosity is rather low, and it produced the highest survival rate of viable LAB with only $0.6 \log$ cycle reduction on drying. Strawberry, kiwi and pineapple presented the highest acidity (pH $3-4)$ and kiwi presented the lowest rate survival with almost a 3 log cycle reduction. Strawberry however, is highly porous and a high survival rate with a reduction of viable cells around $1 \log$ cycle was observed. In fact, probably due to its high porosity, strawberry was the fruit that presented the highest cell count before drying, $3.7 \times 10^{8} \mathrm{cfu} / \mathrm{g}$, which means a better adherence of cells from the probiotic suspension during immersion. Lactobacillus plantarum death was probably due to the decrease in water content, leading to shrinkage of the cell membrane, to the decrease in cytoplasmic $\mathrm{pH}$ and to an increase in the concentration of fruit acids.

Dried fruit pieces incorporated with L. plantarum were stored at room temperature (ca. $20^{\circ} \mathrm{C}$ ) or at $4^{\circ} \mathrm{C}$ in closed glass bottles in the dark for up to 37 days. Storage in vacuum was not tested because previous work with dried apple cubes revealed poorer results than storage in normal atmosphere (Rêgo et al., 2013). After 3 weeks at room temperature there were no viable cells in any of the dried fruits pieces, except for strawberry, which still contained $9.1 \times 10^{4}$ $\mathrm{cfu} / \mathrm{g}$, although after 37 days there were no viable cells in dried strawberry pieces (data not shown). After 37 days of storage at $4^{\circ} \mathrm{C}$, there was a decrease of 0.5 and $1.5 \mathrm{log}$ cycles in dried kiwi and strawberry pieces, respectively, and 2

IJFS | April $2014 \mid$ Volume $3 \mid$ pages 69-73 
$72 \mid$ Ribeiro et al.

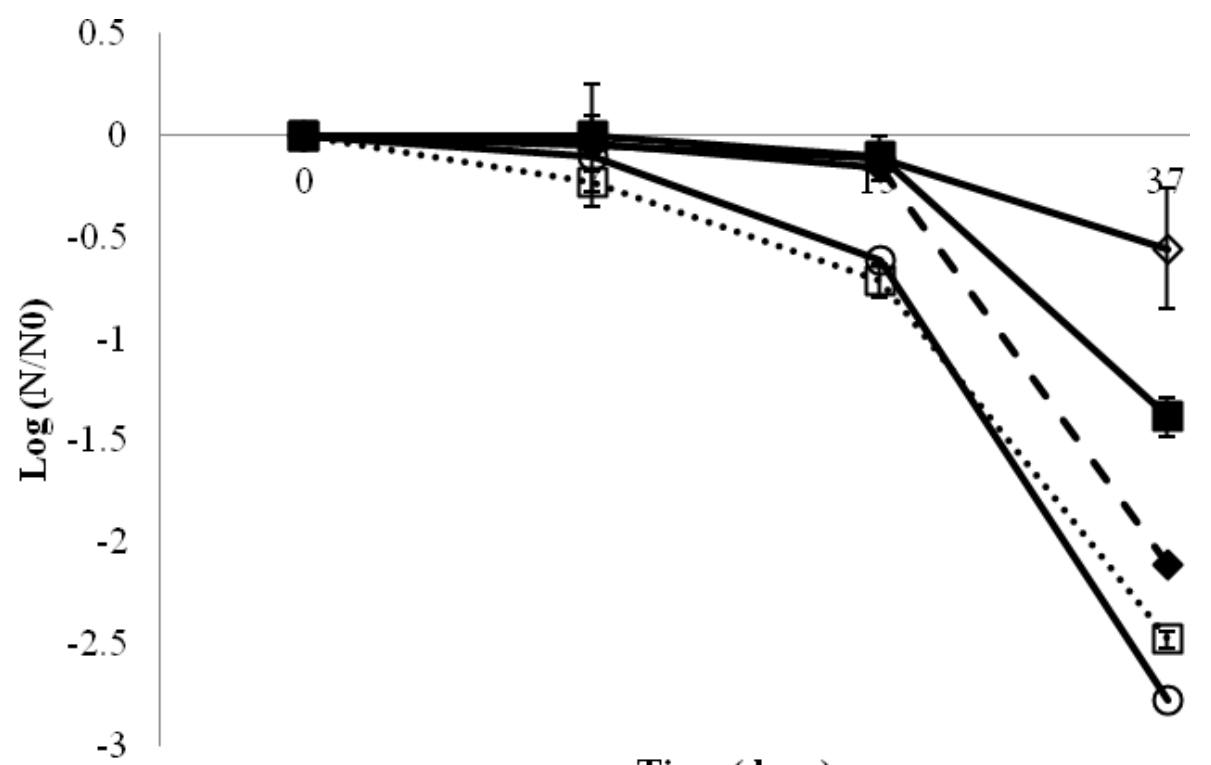

Time (days)

Figure 1: Survival of Lactobacillus plantarum cells in dried, sliced fruits during storage at $4^{\circ} \mathrm{C}$. Legend: $\diamond$, kiwi; $\longrightarrow$, mango; $\mathbf{\square}$, strawberry; ... $\square .$. , pineapple; $\circ$, banana. Error bars indicate standard deviation

to 2.5 log cycles in mango, pineapple and banana dried pieces (Fig. 1). After this time, dried strawberry pieces contained $1.9 \times 10^{6} \mathrm{cfu} / \mathrm{g}$; kiwi presented only $1.5 \times 10^{5} \mathrm{cfu} / \mathrm{g}$, because it had suffered a great reduction in viable cells during drying, as reported above. The latter cell count was very similar to banana, with $1.5 \times 10^{5}$ $\mathrm{cfu} / \mathrm{g}$, because, despite presenting a high survival rate during drying, it suffered a great reduction in viable cells during storage. Dried pineapple pieces presented the lowest viable cell count: 8.0 x $10^{3} \mathrm{cfu} / \mathrm{g}$, which is regarded as much too low when taking into account the objectives. Porosity seems to play a greater role than acidity of the fruit tissue in the incorporation of $L$. plantarum in the fruit matrix during immersion, followed by drying and subsequent storage, and, among the fruits studied in this research, strawberry seemed to be the fruit most efficacious in promoting a high survival rate, with $3.6 \times 10^{7} \mathrm{cfu} / \mathrm{g}$ after 15 days of storage at $4^{\circ} \mathrm{C}$. After the same time, banana and mango presented $2.1 \times 10^{7} \mathrm{cfu} / \mathrm{g}$ and $1.3 \times 10^{7} \mathrm{cfu} / \mathrm{g}$, respectively. In previous research with apple cubes, storage at $4^{\circ} \mathrm{C}$ resulted in a loss of viability of $L$. plantarum of only $1 \mathrm{log}$ cfu/g even after 65 days of storage (Rêgo et al., 2013). This implies apple is a better fruit matrix than strawberry for cell survival; apple tissue also being very porous. Other studies suggest apple as a matrix for the incorporation of probiotic strains as a way to improve their viability in foods (do Espirito Santo, Perego, Converti, \& Oliveira, 2011). As was also observed by Rêgo et al. (2013), storage at $4^{\circ} \mathrm{C}$ was the best way to preserve probiotic cell viability in dried pieces of strawberry, banana, mango, pineapple and kiwi.

\section{Acknowledgements}

This work was supported by National Funds from FCT - Fundação para a Ciência e a Tecnologia through project PEst-OE/EQB/LA0016/2011. Financial support for author Joana Silva was provided by Postdoctoral fellowship SFRH/BPD/35392/2007 (FCT). 
Dried fruits with probiotic $\mid 73$

\section{References}

Alegre, I., Vinas, I., Usall, J., Anguera, M., \& Abadias, M. (2011). Microbiological and physicochemical quality of fresh-cut apple enriched with the probiotic strain lactobacillus rhamnosus gg. Food Microbiology, 28(1), 59-66. doi:10.1016/fm.2010.08.006

do Espirito Santo, A. P., Perego, P., Converti, A., \& Oliveira, M. N. (2011). Influence of food matrices on probiotic viability - a review focusing on the fruity bases. Trends in Food Science \& Technology, 22(7), 377385. doi:10.1016/j.tifs.2011.04.008

Fito, P., Chiralt, A., Betoret, N., Gras, M., Chafer, M., Martinez-Monzo, J., ... Vidal, D. (2001). Vacuum impregnation and osmotic dehydration in matrix engineering - application in functional fresh food development. Journal of Food Engineering, 49(2-3), 175-183. doi:10.1016/S02608774(00)00220-X

Golowczyc, M. A., Mobili, P., Garrote, G. L., Abraham, A. G., \& De Antoni, G. L. (2007). Protective action of lactobacillus kefir carrying s-layer protein against salmonella enterica serovar enteritidis. International Journal of Food Microbiology, 118(3), 264-273. doi:10 . 1016 / j . ijfoodmicro.2007.07.042

Golowczyc, M. A., Silva, J., Abraham, A. G., De Antoni, G. L., \& Teixeira, P. (2010). Preservation of probiotic strains isolated from kefir by spray drying. Letters in Applied Microbiology, 50(1), 7-12. doi:10 . 1111/j.1472-765X.2009.02759.x

Lourens-Hattingh, A. \& Viljoen, B. (2001). Yogurt as probiotic carrier food. International Dairy Journal, 11(1-2), 1-17. doi:10.1016/ S0958-6946(01)00036-X

Mattila-Sandholm, T., Myllarinen, P., Crittenden, R., Mogensen, G., Fonden, R., \& Saarela, M. (2002). Technological challenges for future probiotic foods. International Dairy Journal, 12(2-3, SI), 173182. NIZO Dairy Conference on Food Microbes, EDE, NETHERLANDS, JUN, 2001. doi:10.1016/S0958-6946(01)00099-1

Palafox-Carlos, H., Ayala-Zavala, J. F., \& Gonzalez-Aguilar, G. A. (2011). The role of dietary fiber in the bioaccessibility and bioavailability of fruit and vegetable antioxidants. Journal of Food Science, 76(1), R6-R15. doi:10.1111/j.1750-3841.2010. 01957.x

Rêgo, A., Freixo, R., Silva, J., Gibbs, P., Morais, A. M. M. B., \& Teixeira, P. (2013). A functional dried fruit matrix incorporated with probiotic strains: lactobacillus plantarum and lactobacillus kefir. Focusing on Modern Food Industry, 2(3), 138-143.

Weinbreck, F., Bodnar, I., \& Marco, M. L. (2010). Can encapsulation lengthen the shelf-life of probiotic bacteria in dry products? International Journal of Food Microbiology, 136(3), 364-367. doi:10.1016/j . ijfoodmicro.2009.11.004 